\title{
Social communication of seniors
}

\section{[Socialna komunikacia seniorov]}

\author{
Ctibor Hatar
}

DOI: $10.18355 /$ XL.2019.12.03.01

\begin{abstract}
The submitted study is the author's output from solving the research project VEGA no. 1/0001/18 called Preparation for aging and old age - possibilities of andragogical intervention. The study explains the concept of social communication that is perceived here as the key psychical need of people in the old age. The author looks at social communication from chosen sciences, and he deals, in more detail, with functions, motives, specific features, and barriers in social communication with seniors. He also offers possibilities of developing social communication in the senior age.
\end{abstract}

Key words: social communication, psychic needs of seniors, seniors, functions, motives, specifics, and barriers of social communication, possibilities of development of social communication

\begin{abstract}
Abstrakt
Predkladaná štúdia, ktorá je autorovým výstupom z riešenia výskumného projektu VEGA č. 1/0001/18 s názvom Príprava na starnutie a starobu - možnosti andragogickej intervencie, približuje sociálnu komunikáciu ako kl'účovú psychickú potrebu osôb v seniorskom veku. Autor na sociálnu komunikáciu nazerá cez prizmu vybraných vied a bližšie sa venuje funkciám, motívom, špecifikám a bariéram sociálnej komunikácie so seniormi, ako aj možnostiam rozvíjania sociálnej komunikácie v seniorskom veku.

Kl’účové slová: sociálna komunikácia, psychické potreby seniorov, seniori, funkcie, motívy, špecifiká a bariéry sociálnej komunikácie, možnosti rozvíjania sociálnej komunikácie
\end{abstract}

\section{Úvod}

O sociálnej komunikácii v jej rozmanitých podobách sa neraz diskutuje ako o psychickej potrebe, o klúčovej alebo sociálnej kompetencii či o interakčnom procese v spoločenskom živote každého človeka, seniorov $\mathrm{z}$ tejto skupiny nevynímajúc. Sociálna komunikácia sprevádza psychosociálny vývin každého jednotlivca od narodenia až po smrt' (porovnaj napr. Langmeier, Krejcirova, 1998; Vagnerova, 2000), a zároveň sa svojím spôsobom priamo premieta $\mathrm{v}$ spoločenských a občianskych kompetenciách a v kompetencii komunikovat'v materinskom a cudzom jazyku, o ktorých sa zmieňuje Odporúčanie Európskeho parlamentu a rady o klúčových kompetenciách pre celoživotné vzdelávanie vo svojej prílohe Klúčové kompetencie pre celoživotné vzdelávanie - európsky referenčný rámec. N. Chomsky (1966, in: Vybiral, 2009: 48) chápe pod kompetenciou v psycholingvistickom kontexte schopnost' človeka $\mathrm{v}$ danom jazyku neobmedzene vytvárat' nové vety. „Človek pozná a ovláda systém znakov, rozumie pravidlám jeho kombinatoriky, vie ho správne použit’ a pozná, ak je použitý nesprávne“ (Vybiral, 2009: 48). Uvádzané vymedzenie akcentuje predovšetkým jazykový rozmer (sociálnej) komunikácie. Treba ale uviest', že sociálna komunikácia má vo svojom základe aj sociálny rozmer, ktorý zdôrazňuje napr. M. Hupkova (2010: 141), ked’ uvádza, že sociálna komunikácia je jednou zo sociálnych kompetencií človeka. Na strane druhej V. Strnadova (2011: 26)

XLinguae, Volume 12, Issue 3, June 2019, ISSN 1337-8384, eISSN 2453-711X 
píše o sociálnej komunikácii ako o interakcii pomocou verbálnych alebo neverbálnych kódovaných symbolov.

Viaceré z popisovaných atribútov sociálnej komunikácie prezentujeme v našej štúdii, avšak s dôrazom na seniorský vek, hoci mnohé v práci citované publikácie sa (sociálnej) komunikácii venujú skôr všeobecne.

\section{Sociálna komunikácia ako kl’účová psychická potreba seniorov}

P. Hartl a H. Hartlova (2010: 433) definujú potrebu ako ,stav človeka, ktorý znamená porušenie vnútornej rovnováhy (homeostázy) či nedostatok vo vonkajších vzt’ahoch osobnosti“. Azda najznámejšia sa javí hierarchia potrieb A. Maslowa, ktorý rozlišuje nižšie (fyziologické) a vyššie (psychogénne) potreby (Hartl, Hartlova, 2010: 179).

Samotná prax dosvedčuje, že potreby človeka variujú s jeho vekom, sociálnym statusom, zdravotným stavom a vplyvom mnohých d'alších vonkajších i osobnostných faktorov. Odchodom človeka z pracovného života, v dôsledku dosiahnutia starobného dôchodku, sa neraz od fundamentov mení jeho osobný i spoločenský život (viac o tom napr. Vagnerova, 2000; Balogova, 2005; Haskovcova, 2010; Krivohlavy, 2011; Kovac, 2013).

M. Vagnerova (2000: 467-470) bližšie špecifikovala psychické potreby seniorov (a zmeny v nich) v období ranej staroby, ku ktorým zarad’uje potrebu stimulácie (súvisí s dostatočným prísunom zmysluplných aktivít a podnetov, ktoré by staršieho človeka adekvátne napín̆ali), potrebu orientácie a učenia (seniori musia hl'adat' nový životný štýl a učit' sa novým adaptačným stratégiám, potrebným pre zvládanie životných zmien), potrebu aktivity (nájst' pre staršieho človeka činnosti, ktoré by mohol vykonávat', a zároveň by sa pri nich cítil užitočný), potrebu citovej istoty a bezpečia (senior potrebuje byt' niekam zaradený a ostatnými členmi spoločenstva akceptovaný), potrebu sebarealizácie (hl'adanie nového spôsobu sebarealizácie a sebapotvrdenia) a potrebu otvorenej budúcnosti (seniori sa musia vyrovnat' s realitou, že už nebudú vykonávat' profesijnú rolu a musia si nájst' iný zmysel svojho života).

Z výskumu, ktorý sme realizovali v takmer všetkých krajoch Slovenska v zariadeniach pre seniorov na vzorke 259 respondentov, ktorými boli inštitucionalizovaní seniori, vyplynulo, že spoločenské posedenia $(50,97 \%)$, spoločné stretnutia so seniormi $z$ iných zariadeni $(35,91 \%)$ a hranie spoločenských hier (31,66\%) ako konkrétne podoby sociálnej komunikácie (resp. interakcie) patria k tým aktivitám, o ktoré prejavili seniorskí klienti najväčší záujem (Hatar, 2014: 43-44). Svojím spôsobom aj výskum N. Hrapkovej (2008: 32-33) na vzorke 841 respondentov, ktorými boli poslucháči U3V, resp. jej podobných inštitúcií z viacerých krajín, potvrdil, že respondenti vidia význam štúdia vo vyššom veku v tom, že, okrem iného, majú sociálny kontakt a spoznávajú nových l'udi (53 \%). Aj výskum B. Balogovej (2008: 20), do ktorého sa zapojilo 51 študentov U3V PU v Prešove, dokazuje, že druhým najpočetnejšie zastúpeným motívom, prečo sa rozhodli pre toto štúdium, bolo stretávanie sa s l'ud'mi a nadobúdanie nových sociálnych kontaktov (61 $\%)$.

Prax dosvedčuje, no túto skutočnost' potvrdzujú nielen už zmieňované, ale aj rôzne d’alšie výskumné zistenia (napr. Zimermanova, 2012; Lenhardtova, M. et al., 2015; Homolova, E., 2018), že starší l’udia sa zúčastňujú rozmanitých aktivít najmä kvôli sociálnemu kontaktu a sociálnej komunikácii, ktorá je jeho súčast’ou. Preto zvlášt' v tejto fáze života hrajú významnú úlohu rôzne pravidelné i príležitostné činnosti, na ktorých starší l’udia obligatórne alebo fakultatívne participujú. Tieto činnosti môžu mat' tak súkromný (napr. starostlivost' o vnúčatá alebo o iných nesebestačných členov rodiny), ako aj verejný (napr. dobrovol'níctvo, záujmové inštitucionálne vzdelávanie) charakter. 


\section{Význam, špecifiká a limity sociálnej komunikácie so seniormi}

Sociálna komunikácia má svoje miesto v rôznych oblastiach spoločenského života, a zároveň predstavuje predmet skúmania rôznych vied či vedných disciplín, ktoré na ňu nazerajú cez vlastnú prizmu.

Sociológ B. Geist (1992: 175) uvádza, že „sociálna komunikácia je taká komunikácia, ktorej zmysel je orientovaný na partnera (jedinca, sociálny útvar, a pod.) rovnakého druhu, tzn., že je interakčným procesom vzájomného dorozumievania, ktorým sú medzi partnermi spravidla rovnakého druhu oznamované, príp. vymieňané konvencionálne znaky, platné $\mathrm{v}$ určitom referenčnom systéme významov, reprezentujúcich intendované významy“. Psychológovia P. Hartl a H. Hartlova (2010: 259-260) konštatujú, že sociálna komunikácia netkvie iba v obyčajnom prenose informácií, ale predpokladá aj (ich) porozumenie, v podstate predstavuje partikulárnu súčast' (prípad) interakcie (porovnaj tiež interakcia a sociálna interakcia: Hartl, Hartlova, 2010: 227). M. Gondova (1999: 16) taktiež píše, že „súčast’ou sociálnej interakcie a percepcie je aj sociálna komunikácia“. Podobne sa zmieňuje o komunikácii a interakcii aj K. H. Delhees (1994: 12), ktorý vysvetl'uje rozdiel medzi nimi, pričom raz popisuje interakciu a potom zase komunikáciu ako nadradený pojem. Autor sumarizujúc uvádza, že „pri komunikácii sú silnejšie zdôrazňované obsahy interpersonálnej situácie a ich význam pre interakčného partnera a pri interakcii vzt’ah medzi partnermi a jeho význam pre nich“ (Delhees, 1994: 12). V. Strnadova (2011: 26) poznamenáva, že ,interakcia sa môže v pozitívnej podobe realizovat' ako kooperácia alebo participácia, konsenzus (dohoda) alebo akomodácia (prispôsobenie). V negatívnej podobe ako kompetícia (sút'aživost'), rivalita (súperenie), diskriminácia, konflikt alebo boj“.

Sociálna komunikácia, podobne ako pedagogická komunikácia, má niekol'ko rovín, zjednodušene môžeme hovorit' o obsahovej rovine, procesuálnej rovine a o vztahovej rovine (Gavora a kol., 1988, in: Sutakova, Ferencova, Zahatnanska, 2017: 15), i ked' M. Hupkova (2010: 144) uvádza iba obsahovú (denotatívnu) a formálnu (konotatívnu) úroveň sociálnej komunikácie.

Ako sme už naznačili na inom mieste našej štúdie, sociálna komunikácia má pre seniorov vel'ký význam. Z. Vybiral (2009: 31-32) popisuje sedem funkcií komunikácie, a to informatívnu (informovat'), inštruktážnu (inštruovat'), persuazívnu (presvedčit'), vyjednávaciu/ operatívnu (vyjednat', dohodnút' sa), zábavnú (pobavit'), fatickú/kontaktnú (kontaktovat' sa) a sebaprezentačnú (predviest' sa) funkciu. J. Gabura (2010: 13), odvolávajúc sa na iných autorov, uvádza d'alšie funkcie sociálnej komunikácie, ako napr. výchovno-vzdelávacia, socializačná, motivačná, úniková a ventilačná, ktoré sa spolu s predchádzajúcimi funkciami v nemalej miere odrážajú aj v sociálnej komunikácii seniorov. Motivácia k účasti na (sociálnej) komunikácii je u každého seniora iná. Vo všeobecnosti možno rozlišovat' niekol'ko motívov komunikácie, ako napr. kognitívna motivácia (senior sleduje odovzdanie nejakej myšlienky, poznatku, vyjadrenie názoru a pod.), zistovacia a orientačná motivácia (senior sa pýta, aby sa lepšie orientoval v názoroch, postojoch, témach, o ktorých sa baví, a pod.), združovacia motivácia (senior vstupuje do komunikácie, pretože má potrebu nadväzovat' sociálne kontakty), sebapotvrdzovacia motivácia (ide o potvrdenie si vlastnej ceny), adaptačná motivácia (senior komunikáciou vyjadruje svoje postavenie, sociálne roly, zároveň sa prispôsobuje prostrediu atd'.), „presilová“ motivácia (vychádza z potreby človeka uplatnit' sa, upútat' na seba pozornost' a pod.), pôžitkárska motivácia (súvisí napr. s potrebou človeka oddýchnut' si, zabavit' sa a pod.), existenciálna motivácia (komunikácia, ktorá dáva zmysel života) a i. (Vybiral, 2009: 33-35). 
Komunikácia so seniormi $\mathrm{v}$ rôznych sociálnych situáciách (v rodine, medzi priatel'mi, na verejnosti, v d’alšom vzdelávaní a pod.) má svoje špecifiká, nehovoriac o osobitostiach komunikácie so seniormi vôbec. A. Pokorna (2010: 54) menuje faktory, ktoré ovplyvňujú schopnost' seniora prijímat' obsah komunikácie, a to sú fyzické, psychické, kognitívne a psychosociálne zmeny. Ďalej menuje činitele, ktoré ovplyvňujú schopnost' seniora dekódovat' obsah komunikácie, ako napr. súčasný psychický a fyzický stav, kognitívne zmeny, temperament, charakter, vzdelanie a pod. Poslednú skupinu faktorov tvoria tie, ktoré ovplyvňujú schopnost'seniora produkovat' nové obsahy či reakcia na pôvodnú informáciu. Ide o nasledovné faktory: súčasný psychický a fyzický stav, kognitívne zmeny, vekové osobitosti sémantickej a epizodickej pamäti, schopnost' slovnej produkcie a d’alšie (Pokorna, 2010: 54).

Neraz sú nezvládnuté pravidlá komunikácie so seniormi pôvodcom medzigeneračných, ale aj vnútrogeneračných konfliktov ${ }^{1}$, nezáujmu seniorov o komunikáciu, nepochopenia sprostredkovaného obsahu a pod. M. Hauke (2014: 8687) preto odporúča rešpektovat' určité pravidlá pri (sociálnej) komunikácii so seniormi, a to: 1) Nedávat' rady, pokial' o ne senior nestojí. 2) Rešpektovat' seniora aj s jeho zvláštnost'ami. 3) Vnímat' želania seniora a nebrat' ich na l'ahkú váhu. 4) Pracovat' s príbehom seniora, ktorý nám rozpráva. 5) Nepasovat' sa do úlohy záchrancu a riešit' problémy za seniora. 6) Nebagatelizovat' problémy seniora. 7) Komunikovat' so seniorom takým spôsobom, ktorý zodpovedá jeho veku.

Faktom však zostáva, že jednoduchostou (s prihliadnutím na vek, schopnosti, zdravotné obmedzenia a i.), usporiadanostou (obsahu komunikácie), stručnost'ou a podnetnostou (zaujímavost', aktuálnost' a emočná stránka obsahu komunikácie) možno docielit', že komunikácia (so seniormi) bude zrozumitel'ná (Hauke, 2014: 87). Autorka d'alej uvádza, že v komunikácii so staršími l'ud'mi treba hovorit' adekvátne nahlas, správne artikulovat', prihliadat' na fyzický stav a iné zdravotné obmedzenia, používat' slovník staršej generácie, trpezlivo počúvat', využívat' taktilnú komunikáciu a prispôsobit' im tempo reči (Hauke, 2014: 88).

Proces starnutia, ktorý sa prejavuje voblasti biologickej, psychickej, sociálnej a duchovnej (bližšie o tom napr. Cornanicova, 1998; Vagnerova, 2000; Hotar, Paska, Perhacs et al., 2000; Balogova, 2005; Krivohlavy, 2011; Kovac, 2013 a i.), i samotná staroba neraz prinášajú do života starnúceho a starého človeka rôzne prekážky, s ktorými sa musí vyrovnat', príp. ich preklenút'. Rôzne bariéry sa objavujú aj v rovine komunikačnej. M. Venglarova (2007: 74-75) ich člení do troch skupín, a to bariéry na strane seniora (neochota, nedôvera, obavy, tabu témy, únava, stres, úzkosti a i.), bariéry na strane pracovníka, príp. možno dodat' komunikačného partnera (strach zo závažných tém, nedostatok času, zlá skúsenost' so seniorom a i.) a bariéry, ktoré sa vyskytujú v prostredi (hluk, absentujúce súkromie, zhon a d’alšie). Autorka d'alej správne poznamenáva, že pokial' senior fyzicky trpí v dôsledku rôznych zdravotných problémov, ktoré má, jeho záujem o spoločenskú rovinu komunikácie klesá (Venglarova, 2007: 75). A. Pokorna (2010: 53) píše o vnútorných bariérach, ku ktorým radí napr. obavy z neúspechu, negatívne emócie, nepripravenost', fyzické nepohodlie, chorobu a prekážky, vyplývajúce z prežívania či zdravotného stavu seniora, a o vonkajšich bariérach, medzi ktoré počíta napr. hluk, šum, vizuálne rozptýlenie, neschopnost' počúvat' a prekážky z vonkajšieho prostredia.

V sociálnej komunikácii so seniormi hrajú významnú (negatívnu) rolu viaceré z uvádzaných bariér, ktoré je potrebné podl'a možností eliminovat'. Osobitnú pozornost' si zasluhujú aj nevhodné spôsoby komunikácie so staršími l'ud'mi, ako

$1 \quad$ B. Zapletal a J. Misikova (2002: 31) sa pri výklade pojmu sociálna mobilita, t. j. „pohyb jednotlivcov a skupín v sociálnej štruktúre“, zmieňujú o intrageneračnej (pohyb v rámci jednej generácie) a intergeneračnej (pohyb medzi dvomi alebo viacerými generáciami) mobilite. Uvádzaný model sa dá uplatnit' aj v nami riešenej problematike. 
napr. elderspeak, directive speech, bossy talk, baby talk, newspeak, nursing speak alebo overly nurturing talk (viac o nich: Pokorna, 2010: 61-67).

V predkladanej štúdii sme venovali zvýšenú pozornost' seniorom bez závažnejších (mentálnych) zdravotných obmedzení, akým je napr. Alzheimerova choroba, ktoré akiste ovplyvňujú aj kvantitu a kvalitu sociálnej komunikácie seniorov medzi sebou navzájom, s rodinou, opatrovatel'mi a osobami/inštitúciami z externého sociálneho prostredia. Bližšie sa komunikácii s touto špecifickou skupinou starších osôb venujú rôzne publikácie (napr. Venglarova, 2007; Jirak, Holmerova, Borzova et al., 2009; Hauke, 2014 a d'alší). Len na okraj uvádzame, že okrem zdravotného stavu vplýva na kvalitu komunikácie ešte mnoho d'alších faktorov, ktoré J. Gabura (2010: 35-36), na základe iných prác, zhrnul nasledovne: osobnost' komunikačných partnerov, kvalita percepcie, typ prostredia, participácia d’alších osôb, vonkajší vzhl'ad komunikačných partnerov, vzt'ah k adresátovi, recipročný vzt’ah komunikačných partnerov, kultúrny a časový kontext, motivácia, komunikačné normy, atmosféra a médiá prenosu.

\section{Namiesto záveru}

Okrem sociálneho kontaktu a sociálnej komunikácie, zastúpenej v bežnom živote seniorov, existujú aj profesionálne ponúkané aktivity na rozvíjanie komunikačných zručností (spôsobilostí), či sociálnej komunikácie ako takej. Jednou z nich je aj výcvik personálnych a sociálnych spôsobilostí, ktorý sa môže realizovat' tak u sebestačných seniorov, a to napr. počas štúdia na univerzite tretieho veku (viac o tom: Hupkova, Zimermanova, 2012), ako aj u nesebestačných seniorov, žijúcich $\mathrm{v}$ zariadení sociálnych služieb, a to napr. v rámci rôznych povinných a/alebo nezáväzných aktivít (bližšie o tom: Zakon c. 448/2008 Z. z. o socialnych sluzbach v zneni neskorsich predpisov; Hatar, 2014). Ďalšou z možností na rozvíjanie sociálnej komunikácie v starobe je aj cudzojazyčné vzdelávanie, ktoré je taktiež zamerané na nadobúdanie či rozvíjanie komunikačných zručností (spôsobilostí), i ked' v cudzom jazyku. E. Stranovska (2011: 34) uvádza, že „učenie sa cudziemu jazyku v sebe zahŕn̆a nielen osvojovanie si výslovnosti, pravopisu, gramatických pravidiel, komunikatívnych zručností a pod., ale aj zmenu seba samého prostredníctvom osvojenia si nových sociálnych noriem, mravov, zvykov kultúry cudzieho jazyka, čo má významný vplyv na sociálnu povahu jednotlivca. Posilňuje sa interkultúrne povedomie, poznanie iných kultúr, zvyklostí a uvedomovanie si vlastnej identity“. E. Homolova (2018: 15) potvrdzuje, že seniori participujú na cudzojazyčnom vzdelávaní aj kvôli sociálnym kontaktom, spoločenskej angažovanosti, zmysluplnému prežívaniu vol'ného času, zvládaniu zmien, vyplývajúcich z odchodu z pracovného života, ako aj kvôli udržovaniu vlastných psychických a telesných síl. V našich podmienkach sa problematike cudzojazyčného vzdelávania seniorov venovali napr. C. Hatar a S. Grofcikova (2016), C. Hatar (2016), C. Hatar, P. Jedlickova a M. Muller de Morais (2017), C. Hatar a P. Jedlickova (2018), E. Homolova (2018) a d’alší. V neposlednom rade sa na rozvíjanie sociálnej komunikácie u seniorov môže využit' aj medzigeneračné učenie. P. Jedlickova (2017: 29), na základe iných autorov, uvádza viaceré benefity medzigeneračného učenia pre seniorov, medzi inými aj rozvoj sociálnych zručností. ${ }^{2}$ M. Hupkova (2010: 8) konštatuje, že „dôležité sociálne spôsobilosti sa vzt'ahujú k procesom sociálnej percepcie, sebapoznávania a poznávania druhých, ku komunikácii, zvládania konfliktov a náročných životných

2 Odborná psychologická literatúra používa namiesto pojmu sociálne, príp. komunikačné zručnosti pojem sociálne, príp. komunikačné spôsobilosti (podrobnejšie o tom napr. Hupkova, 2010).

XLinguae, Volume 12, Issue 3, June 2019, ISSN 1337-8384, eISSN 2453-711X 
situácií“, pričom sociálne spôsobilosti podl’a autorky obsahujú prvky, ktoré sa vzt’ahujú k sebe samému, a prvky, ktoré sa týkajú medzil’udských vzt’ahov.

$\mathrm{Z}$ uvedeného nám vyplýva, že existuje množstvo príležitostí, ako podporovat' spoločenský život seniorov, ktorého súčast'ou je aj samotná sociálna komunikácia, aby aktívne prežívali obdobie vlastnej staroby (k aktívnemu starnutiu vid' napr. Aktiv Altern: Rahmenbedingungen und Vorschläge für politisches Handeln, 2002; Petrova Kafkova, 2012; Repkova, 2012a,b; Butorova et al., 2013).

\section{Bibliographic references}

Aktiv Altern: Rahmenbedingungen und Vorschläge für politisches Handeln. Available online:

http://apps.who.int/iris/bitstream/10665/67215/2/WHO_NMH_NPH_02.8_ger.pdf

BALOGOVA, B. 2008. Edukacia ako zmysel zivota seniora/ky. In: Svet seniora senior vo svete. Presov: PU, pp. 11-26. ISBN 978-80-8068-814-1.

BALOGOVA, B. 2005. Seniori. Presov: Akcent Print. ISBN 80-969274-1-8.

BUTOROVA, Z. et al. 2013. Stvrty rozmer tretieho veku. Desat kapitol o aktivnom starnuti. Bratislava: Institut pre verejne otazky. ISBN 978-80-89345-44-1.

CEVELA, R. - KALVACH, Z. - CELEDOVA, L. 2012. Socialni gerontologie. Uvod do problematiky. Praha: Grada. ISBN 978-80-247-3901-4.

CORNANICOVA, R. 1998. Edukacia seniorov. Vznik, rozvoj, podnety pre geragogiku. Bratislava: UK. ISBN 80-223-1206-1.

DELHEES, K. H. 1994. Was ist soziale Kommunikation? In: Soziale Kommunikation. Psychologische Grundlagen fur das Miteinander in der modernen Gesellschaft. Wiesbaden: VS Verlag fur Sozialwissenschaften, pp. 11-47. ISBN 9783-663-05986-8. Available online: https://link.springer.com/chapter/10.1007/978-3663-05986-8_1

GABURA, J. 2010. Komunikacia pre pomahajuce profesie. Bratislava: UK. ISBN 978-80-223-2752-7.

GEIST, B. 1992. Sociologicky slovnik. Praha: VP. ISBN 80-85605-28-7.

GIDDENS, A. 1999. Sociologie. Praha: ARGO. ISBN 80-7203-124-4.

GONDOVA, M. 1999. Socialna percepcia a socialna komunikacia v podmienkach domovov stredoskolskej mladeze. In: Vychovavatel, vol. 44, n. 3-4, pp. 14-16. ISSN 0139-6919.

HARTL, P. - HARTLOVA, H. 2010. Velky psychologicky slovnik. Praha: Portal. ISBN 978-80-7367-686-5.

HASKOVCOVA, H. 2010. Fenomen stari. 2. vydanie. Praha : HBT. 368 s. ISBN 97880-87109-19-9.

HATAR, C. 2016. Cudzojazycna edukacia institucionalizovanych seniorov (nielen) so zdravotnym postihnutim. In: LLCE, vol. 3, n. Special edition, pp. 69-84. ISSN 24537101. Available online: http://files.jolace.webnode.sk/2000027794f25e511a3/LLCE_2016_special_edition.pdf

HATAR, C. 2014. Kvalita zivota institucionalizovanych seniorov v edukacnom kontexte. Nitra: UKF. ISBN 978-80-558-0701-0.

HATAR, C. - GROFCIKOVA, S. 2016. Foreign language education of seniors. In: JoLaCE, vol. 4, n. 1, pp. 158-179. ISSN 1339-4045. Available online: https://content.sciendo.com/view/journals/jolace/4/1/article-p110.xml

HATAR, C. - JEDLICKOVA, P. 2018. Cudzojazycne vzdelavanie dospelych ako priprava na starobu v Nemecku a Spanielsku. In: Adult education 2017 - in time of resonant social changes. Praha: CAS, pp. 165-175. ISBN 978-80-906894-2-8.

HATAR, C. - JEDLICKOVA, P. - MULLER DE MORAIS, M. 2017. Foreign language education to seniors through intergenerational programmes. In: JoLaCE, vol. 5 , n. 1, pp. 103-117. ISSN 1339-4584. Available online: https://content.sciendo.com/view/journals/jolace/5/1/article-p103.xml 
HAUKE, M. 2014. Zvladani problemovych situaci se seniory nejen v pecovatelskych sluzbach. Praha: Grada. ISBN 978-80-247-5216-7.

HOMOLOVA, E. 2018. Jazykova edukacia seniorov. Banska Bystrica: Belianum. ISBN 978-80-557-1407-3.

HOTAR, V. - PASKA, P. - PERHACS, J. et al. 2000. Vychova a vzdelavanie dospelych. Andragogika. Terminologicky a vykladovy slovnik. Bratislava: SPN. ISBN 80-08-02814-9.

HRAPKOVA, N. 2008. Rozmanitost vo vzdelavani seniorov v krajinach Europy situacia a vysledky prieskumu. In: Svet seniora - senior vo svete. Presov: PU, pp. $27-$ 38. ISBN 978-80-8068-814-1.

HUPKOVA, M. 2010. Rozvijanie socialnych sposobilosti v pomahajucich profesiach. Nitra: UKF. ISBN 978-80-8094-704-0.

HUPKOVA, M. - ZIMERMANOVA, M. 2012. Socialno-psychologicky vycvik ako jedna $\mathrm{z}$ efektivnych foriem edukacie seniorov. In: Medzigeneracne mosty : vstupujeme do roka medzigeneracnej solidarity. Presov: PU, pp. 213-231. ISBN 97880-555-0548-0.

JEDLICKOVA, P. 2014a. Edukacia zdravotne znevyhodnenych dospelych a seniorov v rezidencialnych zariadeniach. Nitra: UKF. ISBN 978-80-558-0611-2.

JEDLICKOVA, P. 2014b. Medzigeneracne ucenie ako jedna $\mathrm{z}$ foriem edukacie seniorov. In: Andragogicka revue, vol. 6, n. 2, pp. 31-37. ISSN 1804-1698.

JEDLICKOVA, P. 2017. Medzigeneracne ucenie v rodinnom prostredi ako prevencia agresivneho spravania u deti. Nitra: UKF. ISBN 978-80-558-1178-9.

JESENSKY, J. 2000. Andragogika a gerontagogika handicapovanych. Praha: Karolinum. ISBN 80-7184-823-9.

JIRAK, R. - HOLMEROVA, I. - BORZOVA, C. et al. 2009. Demence a jine poruchy pameti. Komunikace a kazdodenni pece. Praha: Grada. ISBN 978-80-2472454-6.

KADLUBEKOVA, D. 2015. K niektorym otazkam konstituujucej sa speciálnej andragogiky. In: Vzdelavatelia dospelych a ich andragogicke posobenie. Banská Bystrica: UMB, pp. 321 - 336. ISBN 978-80-557-1008-2.

KAMINSKA, D. 2017. Duchovni rozmer v peci o seniory. Nepublikovana prednaska. Praha: Centrum Seňorina.

KALVACH, Z. et al. 1997. Uvod do gerontologie a geriatrie. 1. dil. Gerontologie obecna a aplikovana. Praha: Karolinum. ISBN 80-7184-366-0.

KELLER, J. 1995. Uvod do sociologie. Praha: SLON. ISBN 80-85850-06-0.

KOVAC, D. 2013. Umne starnut. Fragmenty. Bratislava: VEDA. ISBN 978-80-2241280-3.

KRISTOVA, J. 2009. Komunikacia v osetrovatelstve. Martin: Osveta. ISBN 978-808063-160-3.

KRIVOHLAVY, J. 2011. Starnuti z pohledu pozitivni psychologie. Moznosti, ktere cekaji. Praha: Grada. ISBN 978-80-247-3604-4.

KRYSTON, M. et al. 2011. Zaujmove vzdelavanie dospelych. Teoreticke vychodiska. Banska Bystrica: UMB. ISBN 978-80-557-0211-7.

LANGMEIER, J. - KREJCIROVA, D. 1998. Vyvojova psychologie. Praha: Grada. ISBN 80-7169-195-X.

LENHARDTOVA, M. et al. 2015. Kooperativna edukacia deti a seniorov v rezidencialnych zariadeniach. Presov: PU. ISBN 978-80-555-1534-2.

LIVECKA, E. 1979. Uvod do gerontopedagogiky. Praha: USI pri MS.

MASARIK, P. et al. 1994. Vseobecna a porovnavacia pedagogika. Vybrane kapitoly. Nitra: VSPg. ISBN 80-88-738-16-4.

MATULCIK, J. 2004. Teorie vychovy a vzdelavania dospelych v zahranici. Bratislava: Gerlach Print. ISBN 80-89142-02-8. 
MOTSCHNIG, R. - NYKL, L. 2011. Komunikace zamerena na cloveka. Rozumet sobe i druhym. Praha: Grada. ISBN 978-80-247-3612-9.

Odporucanie Europskeho parlamentu a rady z 18.12.2006 o klucovych kompetenciach pre celozivotne vzdelavanie a Klucove kompetencie pre celozivotne vzdelavanie europsky referencny ramec. Available online:

http://nuczv.sk/images/dokumenty_na_stiahnutie/europske_svetove_dokumenty/kluco ve_kompetencie_pre_celozivotne_vzdelavanie.pdf

ONDRUSOVA, J. 2011. Stari a smysl zivota. Praha: Karolinum. ISBN 978-80-2461997-2.

PACOVSKY, V. 1990. O starnuti a stari. Praha: AVICENUM. ISBN 80-201-0076-8.

PERHACS, J. 2004. Geragogika. Nepublikovane prednasky. Nitra: PF UKF.

PERHACS, J. 2011. Personalizacne a socializacne aspekty rozvoja osobnosti dospelych. 2. upravene vydanie. Praha: Rozlet a Ceska andragogicka spolecnost. ISBN 978-80-904824-4-9.

PETROVA KAFKOVA, M. 2012. Dobrovolnictvi senioru jako soucast aktivniho starnuti. In: Sociologia, vol. 44, n. 2, pp. 212-232. ISSN 1336-8613. Available online: http://www.sav.sk/journals/uploads/05241016Petrova-Kafkova2\%20-

$\% 20$ upravena\%20studia.pdf

PICHAUD, C. - THAREAUOVA, I. 1998. Souziti se starsimi lidmi. Praha: Portal. ISBN 80-7178-184-3.

POKORNA, A. 2010. Komunikace se seniory. Praha: Grada. ISBN 978-80-247-32718.

PORUBSKA, G. - DURDIAK, L. 2005. Manazment vzdelavania dospelych. Nitra: SlovDidac. ISBN 80-969303-0-3.

POZAR, L. 1997. Psychologia osobnosti postihnutych. Bratislava: UK. ISBN 80-2231159-6.

POZAR, L. 2007. Zaklady psychologie ludi s postihnutim. Trnava: TU a VEDA. ISBN 978-80-8082-147-0.

PRUSAKOVA, V. 2005. Zaklady andragogiky I. Bratislava: Gerlach Print. ISBN 8089142-05-2.

RABUSICOVA, M. - BRUCKNEROVA, K. - KAMANOVA, L. - NOVOTNY, P. PEVNA, K. - VAREJKOVA, Z. 2016. Mezigeneracni uceni. Teorie, vyzkum, praxe. Brno: MU. ISBN 978-80-210-8460-5.

REPKOVA, K. 2012a. Dobrovolnictvo v kontexte aktivneho starnutia: konceptualna evolucia a pretrvavajuce stereotypy. In: Rodina a práca, n. 4, 46 s. ISSN 1336-7153.

REPKOVA, K. 2012b. Dobrovolnictvo v sektore dlhodobej starostlivosti a aktivne starnutie. In: Sociologia, vol. 44, n. 4, pp. 451-475. ISSN 1336-8613. Available online: http://www.sav.sk/journals/uploads/09101210Repkova2\%20-\%20OK.pdf

REPKOVA, K. et al. 2010. Dlhodoba starostlivost o starsich na Slovensku a v Europe (I). Neformalna starostlivost. Kvalita. Bratislava: Institut pre vyskum prace a rodiny. ISBN 978-80-7138-130-3.

STRANOVSKA, E. 2011. Psycholingvistika: determinanty osvojovania si a ucenia sa cudzieho jazyka a kultury. Brno: MSD. ISBN 978-80-7392-181-1.

STRIZENEC, M. 2007. Novsie psychologicke pohlady na religiozitu a spiritualitu. Bratislava: Ustav experimentalnej psychologie. ISBN 978-80-88910-24-4. Available online: http://www.psychologia.sav.sk/upload/MS_Novsie-psychologicke-pohladyna-religiozitu-a-spiritualitu.pdf

STRNADOVA, V. 2011. Interpersonalni komunikace. Hradec Kralove: Gaudeamus. ISBN 978-80-7435-157-0.

SERAK, M. 2009. Zajmove vzdelavani dospelych. Praha: Portal. ISBN 978-80-7367551-6.

SUTAKOVA, V. - FERENCOVA, J. - ZAHATNANSKA, M. 2017. Socialna a didakticka komunikacia. Bratislava: Wolters Kluwer. ISBN 978-80-8168-548-4. 
SVEC, S. 2008. Anglicko-slovensky lexikon pedagogiky a andragogiky. Bratislava: Iris. ISBN 978-80-89256-21-1.

SVEC, S. (ed.). 2015. Slovenska encyklopedia edukologie. Bratislava: UK. ISBN 978-80-223-3747-2.

SVEC, S. et al. 1998. Metodologia vied o vychove. Kvantitativno-scienticke a kvalitativno-humanitne pristupy v edukacnom vyskume. Bratislava: IRIS. ISBN 8088778-73-5.

TOKAROVA, A. 2002. K metodologickym otazkam vyskumu a hodnotenia kvality zivota. In: TOKAROVA, A. (ed.). Kvalita zivota v kontextoch globalizacie a vykonovej spolocnosti. Presov: PU, pp. 11 - 29. ISBN 80-8068-087-6.

VAGNEROVA, M. 2000. Vyvojova psychologie. Detstvi - dospelost - stari. Praha: Portal. ISBN 80-7178-308-0.

VENGLAROVA, M. 2007. Problematicke situace v peci o seniory. Prirucka pro zdravotnicke a socialni pracovniky. Praha: Grada. ISBN 978-80-247-2170-5.

VYBIRAL, Z. 2009. Psychologie komunikace. Praha: Portal. ISBN 978-80-7367-3871 .

ZACHAROVA, E. 2016. Komunikace v osetrovatelske praxi. Praha: Grada. ISBN 978-80-271-0156-6.

Zakon c. 568/2009 Z. z. o celozivotnom vzdelavani v zneni neskorsich predpisov. Available online:
predpisy/SK/ZZ/2009/568/20150901

Zakon c. 448/2008 Z. Z. o socialnych sluzbach v zneni neskorsich predpisov. Available online: https://www.slov-lex.sk/pravne-predpisy/SK/ZZ/2008/448/

ZAPLETAL, B. - MISIKOVA, J. 2002. Prehled vybrane sociologicke problematiky. Ostrava: OU. ISBN 80-7042-207-6.

ZIMERMANOVA, M. 2013. Cooperation between Children and Seniors and Its Impact on the Quality of Life in Residential Care Conditions. In: The New Educational Review, vol. 33, n. 3, pp. 19 - 32. ISSN 1732-6729.

ZIMERMANOVA, M. 2012. Kooperacia deti a seniorov v rezidencialnych podmienkach. Nitra: UKF. ISBN 978-80-558-0177-3.

Words: 3865

Characters: 29917 (16,62 standard pages)

doc. PaedDr. Ctibor Határ, PhD.

Department of Pedagogy

Faculty of Education

Constantine the Philosopher University in Nitra

Dražovská cesta 4, 94974 Nitra

Slovakia

chatar@ukf.sk 